\title{
Tensile Properties of Remolded Loess and Undisturbed Loess
}

\author{
Xianglin Peng ${ }^{1 *}$, Chao Sun ${ }^{1,2}$, Yanbo Cao ${ }^{1}$ \\ ${ }^{1}$ Chang'an University, Xi'an 710064, China \\ ${ }^{2}$ Shaanxi Nuclear Industry Engineering Survey Institute Co. Ltd, Xi'an 710000, China
}

Corresponding Author Email: 2012026016@chd.edu.cn

https://doi.org/10.18280/acsm.430209

Received: 8 January 2019

Accepted: 16 March 2019

\section{Keywords:}

remolded loess, undisturbed loess, water content, tensile strength

\begin{abstract}
In the light of previous studies, this paper improves the traditional horizontal axial soil tensile tester, eliminating its defects. Then, the improved tester was applied to test the tensile strength of remolded and undisturbed loess. The tensile properties of the two types of loess were summed up based on the test results. For undisturbed loess, the tensile strength increased with dry density when the water content stayed the same, and decreased with water content when dry density remained the same. For remolded loess, the tensile strength first increased to the peak value and then gradually declined, with the growth in water content. In general, the tensile strength curve of undisturbed loess took the shape of a slope, while that of remolded loess showed the wavy pattern. The difference arises from the loss of bonding force and weakening of structuredness in the remolding process.
\end{abstract}

\section{INTRODUCTION}

Loess is widely distributed across China, especially in the north and northwest, taking up about $6 \%$ of the country's land area [1]. In fact, China has larger loess-covered land than any other country in the world. With the infrastructure boom, loess excavation is inevitable in many construction projects. This calls for in-depth analysis on loess, a soil with unique mechanical properties, in the context of engineering construction [2].

Concerning the mechanical properties of loess, most of the existing studies focus on the structuredness, collapsibility and the influencing factors of compressive shear strength [3-6], failing to consider the tensile strength. However, the tensile properties of loess are critical in many projects and related to various engineering disaster, such as slope slippage, impervious layer cracking, hydraulic fracturing and uneven foundation settlement [7]. If the law of tensile properties of loess is determined, it will be possible to improve soil strength theory and guide engineering practice.

So far, the tensile properties of loess have mainly been studied through experiments, with special attention to the mechanical mechanism and influencing factors [8-10]. Taking water content as the influencing factor, Wang Yanhui et al. [11] examined the tensile properties of undisturbed loess though various types of tests, revealing that the tensile strength is negatively correlated with water content in any test. Through axial fracturing test, Li Chunqing et al. [12] investigated the tensile properties of undisturbed loess, conducted 3D modelling of the test data, and then detailed the relationship between fracture changes, displacement, stress and strain of the specimens. Dang Jinqian et al. [13] attributed the tensile strength of undisturbed loess to the water film of the soil, particle cohesion and matrix suction.

Overall, the existing studies have gained insights into the tensile properties of loess, yet failing to compare the tensile strength of undistributed loess and that of remolded loess. To make up for the gap, this paper improves the horizontal axial soil tensile tester, and uses the improved tester to test the tensile properties of remolded and undistributed loess of different dry densities and water contents. Based on the test data, the author analyzed, summed up and explained the difference between the two types of loess in tensile properties.

\section{METHODOLOGY}

\subsection{Tester improvement}

To overcome its defects, the traditional horizontal axial soil tensile tester was improved in four steps:

Step 1: To counteract the static friction at the bottom, height-adjustable scale bolts were added around the tester to adjust the inclination of the plate [14].

Step 2: The scale and axis were marked, and a manual adjuster was installed to keep the tensile force on the axis, aiming to minimize the error.

Step 3: The glass plate was applied in advance with lubricant (e.g. Vasline), trying to reduce the friction of the sliding specimen.

Step 4: Different instruments could be placed according to the test requirements, making the tester more universal.

The top and side views of the improved tester are provided in Figure 1 below. 


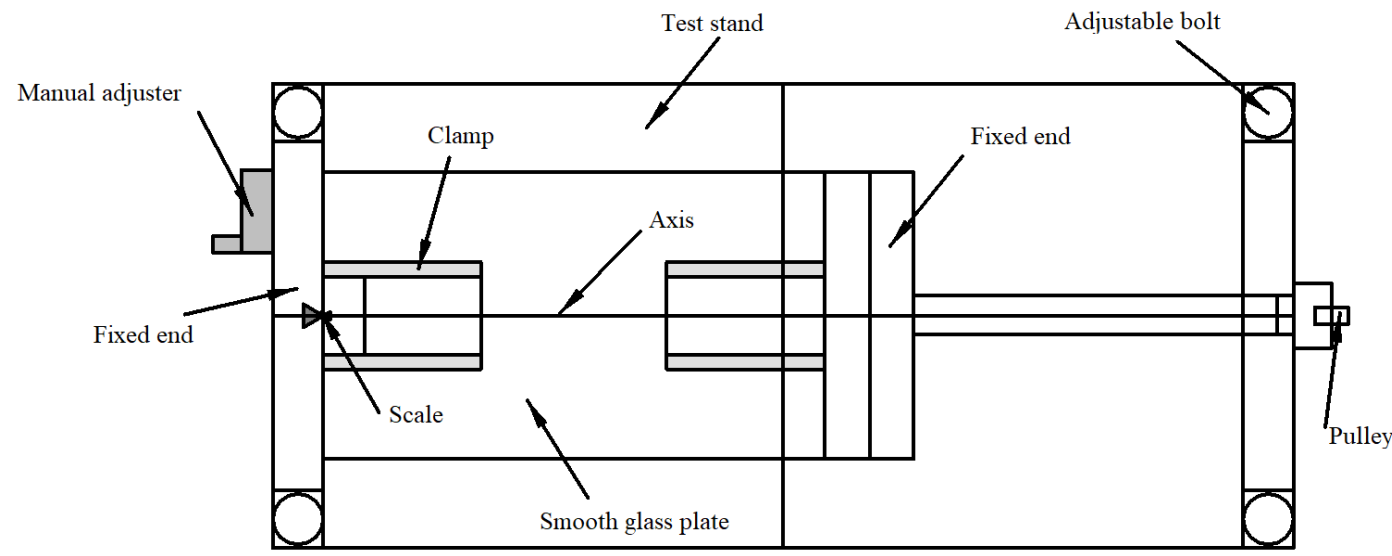

(1) Top view

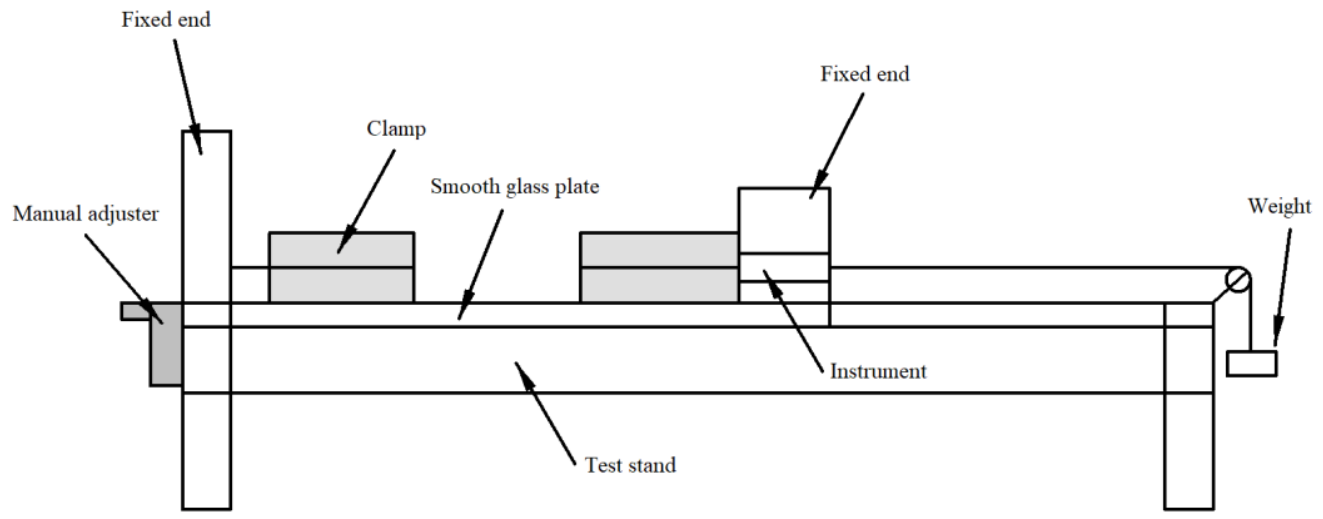

(2) Side view

Figure 1. The improved tester

\subsection{Specimen preparation}

All loess samples were collected at once, from a slope in Luochuan Loess National Geopark, Yan'an, northwestern China's Shaanxi Province. The undisturbed loess was greyish yellow, containing a few grassroots, wormholes and other impurities. It was measured that the loess samples have a plastic limit of $13.7 \%$ and a liquid limit of $28.5 \%$. According to the empirical formulas in the Code for Soil Test of Railway Engineering (TB10102-2010), the optimal water content and maximum dry density of the loess samples were derived as $15.3 \%$ and $1.78 \mathrm{~g} / \mathrm{cm}^{3}$, respectively.

(1) Undistributed loess

With proper clamps, the undistributed loess was shaped into eighteen $15 \mathrm{~cm} \times 5 \mathrm{~cm} \times 5 \mathrm{~cm}$ rectangular blocks in the lab. Next, the dry densities of the specimens were measured. The measured data basically fell in the range $1.20 \mathrm{~g} / \mathrm{cm}^{3}-1.60$ $\mathrm{g} / \mathrm{cm}^{3}$. In the light of the dry density, the specimens were evenly divided into three groups, whose mean dry density was respectively $1.20 \mathrm{~g} / \mathrm{cm}^{3}, 1.44 \mathrm{~g} / \mathrm{cm}^{3}$ and $1.56 \mathrm{~g} / \mathrm{cm}^{3}$ [15]. After that, the specimens in each group were injected with different amounts of water, and subjected to moisturizing curing for $12 \mathrm{~d}$ or more. The curing is to ensure uniform diffusion of water inside each specimen and reduce the test error. After curing, the mean water content of the first specimens in the three groups was $12 \%$, that of the second specimens in the three groups was $14 \%$, that of the third specimens in the three groups was $17 \%$, that of the fourth specimens in the three groups was $18 \%$, that of the fifth specimens in the three groups was $20 \%$ and that of the sixth specimens in the three groups was $23 \%$.

(2) Remolded loess

Some of the collected loess samples were remolded, prepared into remolded specimens with different water contents $(10 \%, 12 \%, 14 \%, 16 \%, 18 \%, 20 \%, 22 \%$ and $24 \%)$ and dry densities $1.35 \mathrm{~g} / \mathrm{cm}^{3}, 1.45 \mathrm{~g} / \mathrm{cm}^{3}, 1.55 \mathrm{~g} / \mathrm{cm}^{3}, 1.65$ $\mathrm{g} / \mathrm{cm}$ and $1.75 \mathrm{~g} / \mathrm{cm}^{3}$ ), and cured for 2-3 days [16].

\subsection{Test procedure}

Step 1: A specimen was placed on the glass plate, after the plate surface was treated with lubricant (e.g. Vasline). Then, the bolts at the four corners were adjusted, keeping the front and rear horizontal. Next, the plate inclination was changed until the specimen was about to slide, thus offsetting the friction. After that, the scale of the plate was adjusted, such that the specimen axis, the plate axis and the pulley axis coincided with each other. The scale was fixed to maintain the specimen axis under the tensile force.

Step 2: In the course of loading, the weights were added in descending order of mass. After adding a weight, the specimen was left to stabilize for $1 \mathrm{~min}$ before adding the next weight

Step 3: During the tensile loading, the tensile change of the specimen was observed continuously. The test was terminated once the specimen was broken. Then, the weight data were recorded, and the instruments were sorted and cleaned.

Step 4: The tensile strength of the specimen can be calculated by: 


$$
\sigma_{t}=\frac{T}{A_{0}} \times 10
$$

The above formula can be rewritten as:

$$
\sigma_{t}=\frac{(m+n / 2) g}{A_{0}} \times 10
$$

\section{TEST RESULTS}

\subsection{Test results on undisturbed loess}

Table 1 lists the test results on undisturbed loess specimens.

Table 1. Test results on undisturbed loess specimens

\begin{tabular}{|c|c|c|c|c|}
\hline $\begin{array}{c}\text { Group } \\
\text { No. }\end{array}$ & $\begin{array}{c}\text { Specimen } \\
\text { No. }\end{array}$ & $\begin{array}{c}\text { Dry } \\
\text { density } \\
\left(\mathrm{g} / \mathrm{cm}^{3}\right)\end{array}$ & $\begin{array}{c}\text { Water } \\
\text { content } \\
(\%)\end{array}$ & $\begin{array}{c}\text { Tensile } \\
\text { strength } \\
(\mathrm{kPa})\end{array}$ \\
\hline \multirow{4}{*}{1} & 1 & 1.20 & 11.56 & 48.48 \\
\cline { 2 - 5 } & 2 & 1.22 & 13.34 & 35.02 \\
\cline { 2 - 5 } & 3 & 1.19 & 15.43 & 28.53 \\
\cline { 2 - 5 } & 4 & 1.21 & 17.07 & 21.29 \\
\cline { 2 - 5 } & 5 & 1.20 & 19.76 & 19.16 \\
\hline \multirow{4}{*}{2} & 1 & 1.18 & 20.68 & 16.93 \\
\cline { 2 - 5 } & 2 & 1.43 & 12.67 & 46.73 \\
\cline { 2 - 5 } & 3 & 1.44 & 14.38 & 33.24 \\
\cline { 2 - 5 } & 4 & 1.47 & 17.40 & 25.84 \\
\cline { 2 - 5 } & 5 & 1.41 & 19.59 & 20.18 \\
\hline \multirow{4}{*}{3} & 6 & 1.46 & 21.27 & 18.47 \\
\cline { 2 - 5 } & 2 & 1.55 & - & - \\
\cline { 2 - 5 } & 3 & 1.57 & 13.25 & 52.67 \\
\cline { 2 - 5 } & 4 & 1.56 & 17.86 & 29.94 \\
\cline { 2 - 5 } & 2 & 1.54 & 19.63 & 24.47 \\
\cline { 2 - 5 } & 6 & 1.57 & 21.17 & 20.62 \\
\hline
\end{tabular}

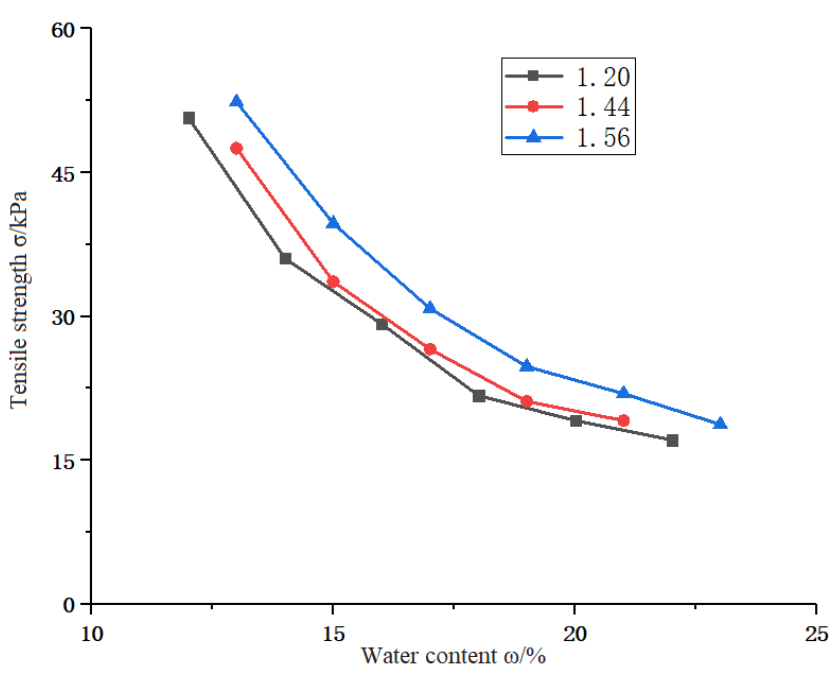

Figure 2. Relationship between tensile strength and water content of undisturbed loess

The relationship between tensile strength and water content of undisturbed loess specimens is presented in Figure 2. It can be seen that the measured tensile strength decreased with the growth in water content. This is because the water film, particle cohesion and matrix suction are all negatively correlated with water content. In addition, the lines in Figure 2 were relatively smooth, and the slope reduced with the growth in water content, indicating that the tensile strength of undisturbed loess changed more and more slowly with the rising water content. As shown in the figure, when the water content remained basically the same, the greater the dry density of a loess sample, the stronger its tensile strength. For undisturbed loess, the tensile strength climbs up as the dry density increases between $1.20 \%-1.56 \%$.

\subsection{Test results on remolded loess}

Table 2 lists the test results on remolded loess specimens.

\begin{tabular}{|c|c|c|c|c|c|c|c|c|}
\hline \multirow{3}{*}{$\begin{array}{l}\text { Dry density } \\
\left(\mathrm{g} / \mathrm{cm}^{3}\right)\end{array}$} & \multicolumn{8}{|c|}{ Water content $/ \%$} \\
\hline & 10 & 12 & 14 & 16 & 18 & 20 & 22 & 24 \\
\hline & $\begin{array}{c}\text { Tensile } \\
\text { strength }(\mathrm{kPa})\end{array}$ & $\begin{array}{c}\text { Tensile } \\
\text { strength }(\mathrm{kPa}) \\
\end{array}$ & $\begin{array}{c}\text { Tensile } \\
\text { strength }(\mathrm{kPa})\end{array}$ & $\begin{array}{c}\text { Tensile } \\
\text { strength }(\mathrm{kPa})\end{array}$ & $\begin{array}{c}\text { Tensile } \\
\text { strength }(\mathrm{kPa})\end{array}$ & $\begin{array}{c}\text { Tensile } \\
\text { strength }(\mathrm{kPa})\end{array}$ & $\begin{array}{c}\text { Tensile } \\
\text { strength }(\mathrm{kPa})\end{array}$ & $\begin{array}{c}\text { Tensile } \\
\text { strength }(\mathrm{kPa})\end{array}$ \\
\hline 1.35 & - & 16.03 & 26.08 & 21.79 & 16.19 & 14.68 & 11.84 & 10.04 \\
\hline 1.45 & 6.70 & 20.24 & 33.05 & 24.96 & 19.65 & 16.65 & 15.21 & 11.47 \\
\hline 1.55 & 8.62 & 25.72 & 38.03 & 30.56 & 23.58 & 18.57 & 16.35 & 13.57 \\
\hline 1.65 & 10.34 & 30.57 & 45.06 & 39.07 & 18.31 & 21.52 & 19.03 & 15.84 \\
\hline 1.75 & 12.43 & 36.92 & 51.79 & 45.24 & 32.04 & 26.05 & 21.23 & 18.95 \\
\hline
\end{tabular}

Table 2. Test results on remolded loess specimens

Figures 3 and 4 respectively display the correlation of tensile strength with water content and dry density of remolded loess specimens.

As shown in Figure 3, with the growth in water content, the tensile strength curve of each specimen first climbed up to a peak point and then went downhill. In other words, the tensile strength first increases to the maximum level and then gradually drops at a decreasing rate, when the water content increased in the range of $10 \%-24 \%$. Moreover, with the increase in dry density, the tensile strength showed a gradual upward trend; the two parameters basically have a positive correlation. Whichever the dry density, the tensile strength always peaked at the water content of $14 \%$, revealing that $14 \%$ is the optimal water content. This content was about $1 \%$ smaller than the previously computed result. The difference may be the result of the curing condition [17].

As shown in Figure 4, when the water content remained the same in the range of $10 \%-24 \%$, the tensile strength of remolded loess augmented at an increasing rate, with the increase of dry density. When the dry density remained the same, the tensile strength of remolded loess peaked at the water content of $14 \%$, indicating that the optimal water 
content of remolded loess is also $14 \%$. The tensile strengthwater content curve of remolded loess obeyed normal distribution: the tensile strength continued to grow as the water content was below $14 \%$, but started to decline as the latter was greater than $14 \%$. For remolded loess, the peak tensile strength and the slope of the relationship curve between tensile strength and dry density both changed constantly, as the water content varied between $10 \%-14 \%$.

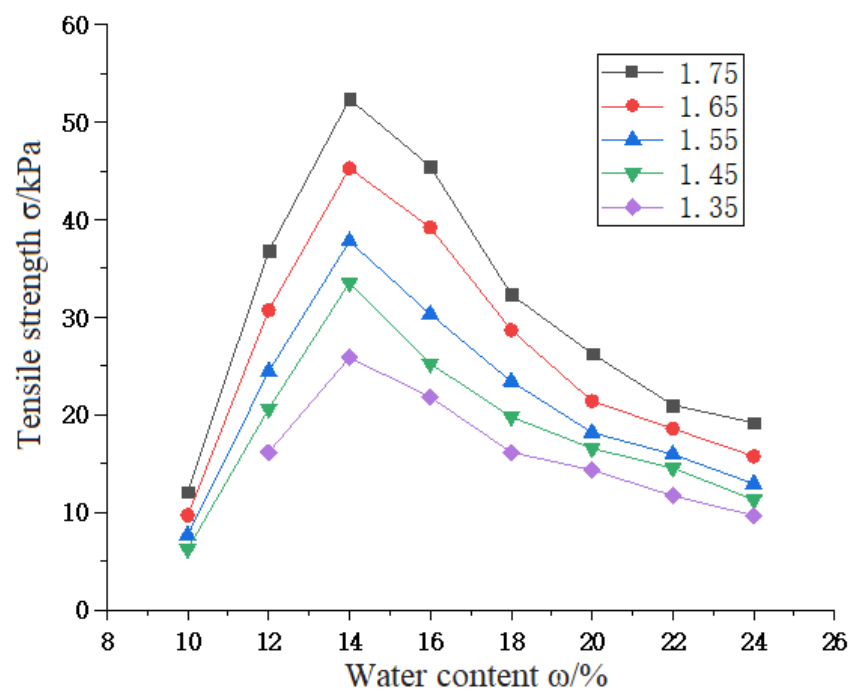

Figure 3. Relationship between tensile strength and water content of remolded loess

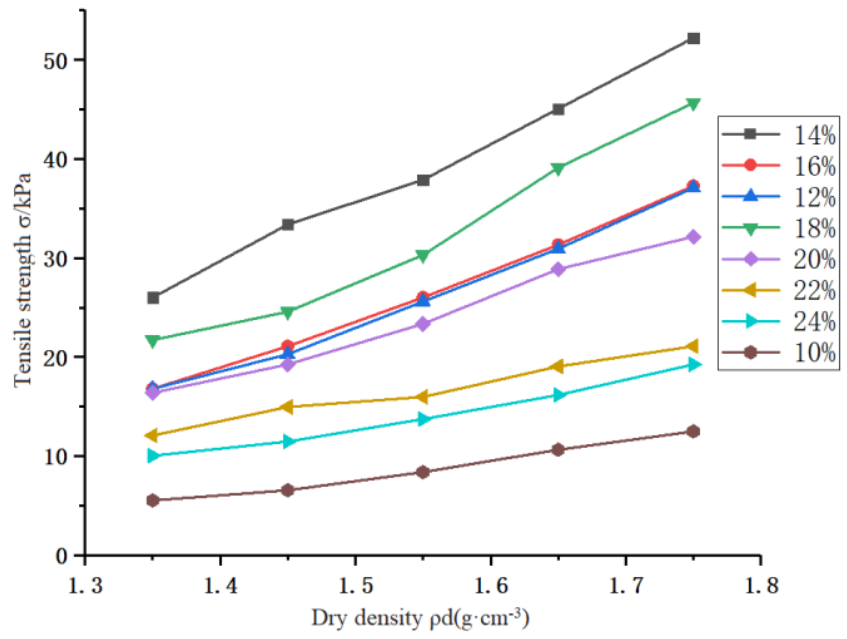

Figure 4. Relationship between tensile strength and dry density of remolded loess

\section{COMPARATIVE ANALYSIS}

The variation in tensile strength of undisturbed loess and remolded loess was plotted at two different dry densities. It can be seen from Figure 5 that, the tensile strength of undisturbed loess continued to decline, without any rebound, as the water content was on the rise. Meanwhile, the tensile strength of remolded loess had a wavy pattern: the strength firstly increased to the peak and then declined.

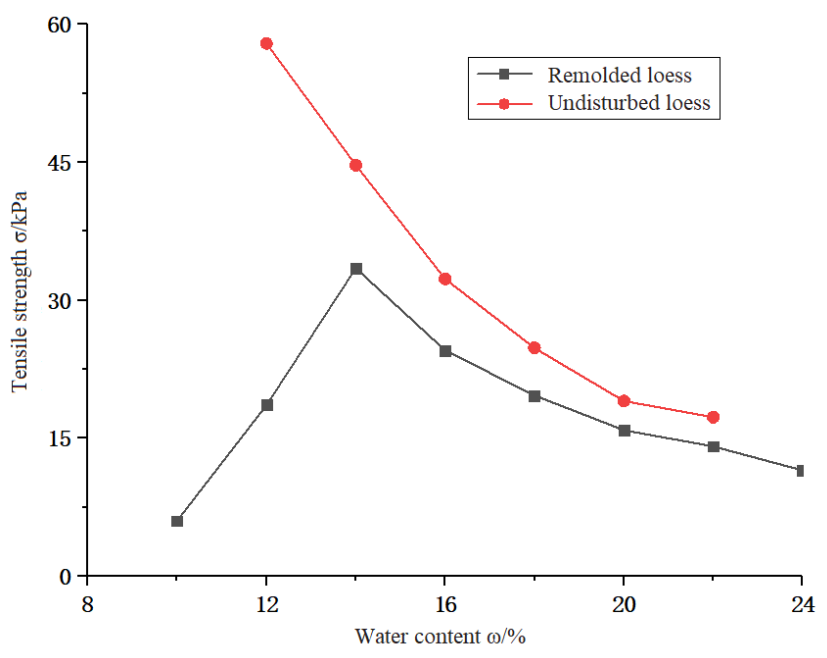

(1) $\rho_{\mathrm{d}}=1.45 \mathrm{~g} / \mathrm{cm}^{3}$

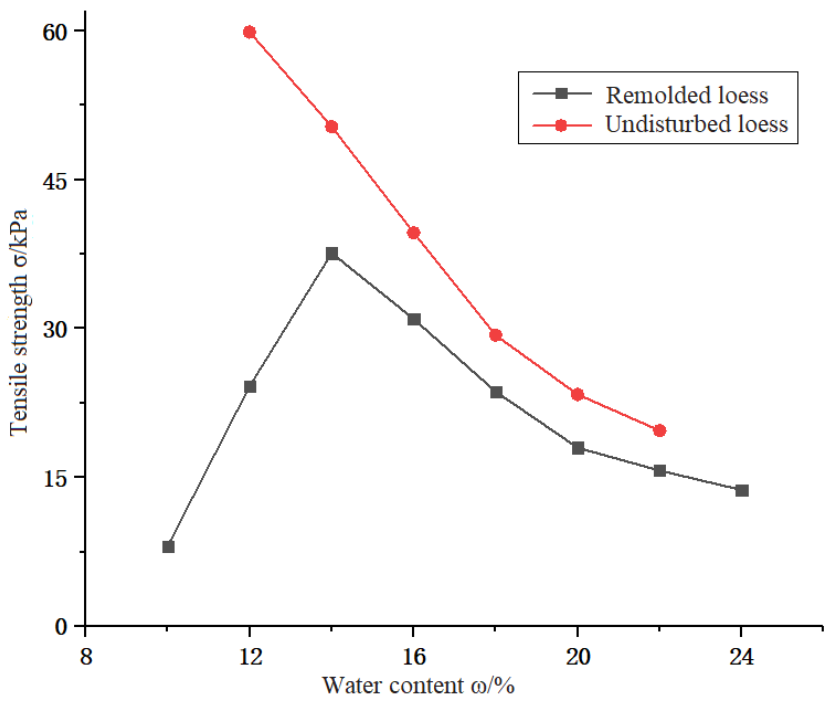

(2) $\rho_{\mathrm{d}}=1.55 \mathrm{~g} / \mathrm{cm}^{3}$

Figure 5. Tensile strength curves at two different dry densities

The comparison shows that both undisturbed and remolded loess have a certain tensile strength, which depends on water content and dry density. When the water content remains the same, the tensile strength of either type of loess increases with dry density. However, when the dry density remains the same, the two types of loess witness different trends in tensile strength. This phenomenon can be explained as follows:

Under natural conditions (e.g. rain, solar radiation, high temperature and severe coldness), all the cementing materials inside undisturbed loess have reacted with soil particles, leaving no chance to bond with water. Thus, the tensile strength of undisturbed loess will not increase with the water content. By contrast, cementing materials within the remolded loess have not fully reacted with water. Thus, the tensile strength of remolded loess will increase with water content, and continue to decrease till breakage after the water content surpasses the critical level.

Furthermore, the remolded loess specimens had lower tensile strength than undisturbed loess specimens. This is because the soil particles are rearranged in remolding, which damages the original cementation state between them. As a result, the tensile strength will grow with the increase in water content, but the specimens cannot reach the optimal stability. 
The analysis shows that the tensile strength of loess is significantly affected by disturbance [18].

\section{CONCLUSIONS}

This paper improves the horizontal axial soil tensile tester, and uses the improved tester to test the tensile properties of remolded and undistributed loess of different dry densities and water contents. Based on the test data, the author analyzed and explained the difference between the two types of loess in tensile properties. The main conclusions are as follows:

(1) To make the traditional tester more scientific and rigorous, height-adjustable scale bolts were added to adjust the inclination of the plate and counteract the static friction; the scale and axis were marked, and a manual adjuster was installed to keep the tensile force on the axis, aiming to minimize the error.

(2) The tensile strength of remolded loess specimens first increased to the peak value and then gradually declined, with the growth in water content. The tensile strength curves generally took the wavy pattern. As for undisturbed loess specimens, the tensile strength increased with dry density when the water content stayed the same, and decreased with water content when dry density remained the same.

(3) The most significant difference between undisturbed and remolded loess in tensile properties lies in the shape of the tensile strength-water content curve at a constant dry density: the tensile strength of undisturbed loess continues to decline, while that of remolded loess exhibits as a wave (first increases to the peak and then gradually decrease). The difference is attributable to the incomplete reaction between cementing materials and water in the remolding process, for the particle cohesion and matrix suction are not optimized.

\section{ACKNOWLEDGMENT}

The authors sincerely acknowledge the financial support from the State Key Program of National Science of China (Grant No. 41630634), Science and Technology Planning Project of Shaanxi (Grant No. 2019SF-233) and Science and Technology Burea of Yulin (Grant No. 2014cxy-04).

\section{REFERENCES}

[1] Li, C.Q. (2015). Study on tensile strength characteristics of loess. Lanzhou Jiaotong University. 2015.

[2] Wu, X.Y., Liang, Q.G., Li, C.Q., Wang, L.L., Sun, W.Y. (2014). Study on tensile properties of remolded loess in Jiuzhou development district, Lanzhou, China. China Earthquake Engineering Journal, 36(3): 562-568. https://doi.org/10.3969/j.issn.1000-0844.2014.03.0562

[3] Wang, L.M., Yuan, Z.X., Wang, G.L. (2013). Study on method for preliminary and detailed evaluation on liquefaction of loess sites. China Earthquake Engineering Journal, 35(1): 1-8. https://doi.org/10.3969/j.issn.10000844.2013.01.0001

[4] Wang, J.E., Xiang, W., Bi, R.N. (2011). Experimental study of influence of matric suction on disintegration of unsaturated remolded loess. Rock and Soil Mechanics, 32(11): 3258-3262. https://doi.org/10.3969/j.issn.1000-
7598.2011.11.010

[5] Jing, Y.L., Wu, Y.Q., Lin, D.J., Hu, Z.P., Li, X.G., Zhang, Z.Q. (2011). Study of relationship between loess collapsibility and index of compaction test. Rock and Soil Mechanics, 32(2): 393-397. https://doi.org/10.3969/j.issn.1000-7598.2011.02.012

[6] Luo, Y.S., Hu, Z.S., Zhang, A.J. (2009). Regularity of relation between structural parameter and strength indexes of unsaturated loess. Rock and Soil Mechanics, 30(4): 943-948. https://doi.org/10.3969/j.issn.10007598.2009 .04 .014

[7] He, S.X. (2016). Experimental research on tensile characteristics of loess. Shijiazhuang Tiedao University, 2016.

[8] Kim, T.H., Hwang, C. (2003). Modeling of tensile strength on moist granular earth material at low water content. Engineering Geology, 69(3/4): 233-244. https://doi.org/10.1016/S0013-7952(02)00284-3

[9] Tamrakar, S.B., Mitachi, T., Toyosawa, Y. (2007). Measurement of soil tensile strength and factors affecting its measurements. Soils and Foundations, 47(5): 911-918. https://doi.org/10.1007/3-540-69873-6_20

[10] Lu, N., Wu, B., Tan, C.P. (2007). Tensile strength characteristics of unsaturated sands. Journal of Geotechnical and Geoenvironmental Engineering, 133(2): 144-154. https://doi.org/10.1061/(asce)10900241(2007)133:2(144)

[11] Wang, Y.H., Ni, W.K., Yuan, Z.H. (2015). Study on the test method for tensile strength of undisturbed loess. Science Technology and Engineering, 15(07): 234237+247. https://doi.org/10.3969/j.issn.16711815.2015.07.045

[12] Li, C.Q., Liang, Q.G., Wu, X.Y., Wang, L.L., Xu, S.C. (2014). Study on the test of tensile strength of remolded loess. China Earthquake Engineering Journal, 36(02): 233-238+248. https://doi.org/10.3969/j.issn.10000844.2014 .02 .0233

[13] Dang, X.Q., Hao, Y.Q., Li, J. (2001). Study on tensile strength of unsaturated loess. Journal of Hohai University (Natural Sciences), 29(6): 106-108. https://doi.org/10.3321/j.issn:1000-1980.2001.06.025

[14] Sun, C. (2017). Study on the test of tensile strength of loess in the south of Jinghe. Chang'an University, 2017.

[15] Yuan, Z.H., Ni, W.K., Tang, C., Huang, C., Wang, Y.H. (2017). Experimental study on tensile strength of loess under dry and wet cycling. Chinese Journal of Rock Mechanics and Engineering, 36(S1): 3670-3677. https://doi.org/10.13722/j.cnki.jrme.2016.0230

[16] Sun, W.Y., Liang, Q.G., Yan, S.H., Ou, E.F., Shao, S.L. (2015). Experimental study on tensile strength of $\mathrm{Q}_{2}$ undisturbed loess in Yan'an Shanxi China. Journal of Geomechanics, 21(03): 386-392.

[17] Sun, W.Y., Liang, Q.G., Ou, E.F., Yan, S.H., Zhang, Y.W. (2015). Comparative experimental study on tensile strength of undisturbed and remolded $\mathrm{Q}_{2}$ Loess from Yan'an Shanxi China. China Civil Engineering Journal, 48(S2): 53-58.

[18] Sun, M.X., Dang, J.Q., Kang, S.X. (2006). Tensile character of disturbed loess. Journal of Xi'an University of Arts and Science (Natural Science Edition), 9(3): 5961 5564.2006.03.015 